\title{
How the climate will change in this century?
}

\author{
Judit BARTHOLY ${ }^{1}$, Rita PONGRÁCZ ${ }^{1}$ and ILDikó PIECZKA ${ }^{1}$
}

\begin{abstract}
In order to support political and economical decision makers by providing climate information for the future, it is essential to analyze regional climate model results. These models are capable to describe the regional climate conditions of individual countries using $25 \mathrm{~km}$ horizontal resolution, whereas global climate models are too coarse for such details. This paper discusses the regional effects of global warming using regional climate model experiments from the PRECIS model developed at the Hadley Centre of the UK Met Office. Since PRECIS was adapted at the Department of Meteorology, Eötvös Loránd University in the recent years, important regional/local conditions could be taken into account during the modelling process. In the experiments of PRECIS, three different emission scenarios (A2, $\mathrm{A} 1 \mathrm{~B}, \mathrm{~B} 2)$ are considered to provide estimations for the $21^{\text {st }}$ century. Our conclusions highlight the significant warming tendency in Hungary, especially in summer. The frequency of cold temperature extremes is projected to decrease significantly while warm extremes tend to occur more often in the future. Furthermore, significant drying is projected in the region, especially, in summer. In winter the precipitation is likely to increase.
\end{abstract}

Keywords: regional climate modelling, PRECIS, temperature, precipitation, extremes

\section{Introduction}

The Intergovernmental Panel on Climate Change (IPCC) started to publish the Fifth Assessment Report (AR5) with the physical science basis (IPCC, 2013). That contribution of IPCC Working Group I clearly states (i.e. as virtually certain with $99-100 \%$ probability) that global warming is detected in the last 110 years on the basis of regular meteorological observations worldwide. The anthropogenic effect is quite evident due to the increased emissions of greenhouse gases, and consequently, their increased atmospheric concentrations compared to the preindustrial values. The concentration of carbon dioxide was $41 \%$ larger

\footnotetext{
${ }^{1}$ Department of Meteorology, Eötvös Loránd University, H-1117 Budapest, Pázmány Péter sétány.1/a. E-mails: bartholy@caesar.elte.hu, prita@nimbus.elte.hu, pieczka@nimbus.elte.hu
} 
in 2012 than a few centuries ago since the global mean levels were $393 \mathrm{ppm}$ and 278 ppm in 2012 and in 1750, respectively (WMO, 2013). The major anthropogenic contributions include the intense fossil fuel use to feed the growing energy demands of the Earth's population. The increases of other greenhouse gas concentrations were also substantial, especially in case of methane with an atmospheric level of about 160\% higher in 2012 than in the 1700s.

Overall, between 1901 and 2012 the global mean annual temperature increased by $0.89^{\circ} \mathrm{C}$ (IPCC, 2013). In Hungary the regional mean annual temperature has increased by about $1{ }^{\circ} \mathrm{C}$ since the beginning of the $20^{\text {th }}$ century (LaKatos, M. and Bihari, Z. 2013). The detected changes mentioned above raise the questions how and what we can project for the future decades of this century. For those purposes, models are needed.

The detected climate changes and the human influence are assessed in climate model simulations. Global climate models (GCMs) contain complex mathematical formulae based on well-known physical laws (i.e. thermodynamics, motion, continuity equations) and they are able to reproduce the past climatic conditions. In order to estimate the likely or possible future conditions, they can be also used. The spatial resolution of a GCM is typically $1-3^{\circ}$, which limits the accuracy of fine scale details in smaller regions (e.g. the Carpathian Basin). For instance, the effect of complex topography cannot be reflected using that coarse resolution.

GCMs serve as driving fine resolution regional climate models (RCMs). The RCMs are limited area models embedded in GCMs (GiongI, F. 1990). Their physical bases are similar to GCMs'; parametrizations typically consider 10-50 $\mathrm{km}$ spatial scales. In Hungary four different RCMs have been adapted for our region. One of the models is the PRECIS model (BARTHOLY, J. et al. 2009b) which is briefly introduced in the next section. Then, the climate change results for Hungary by the middle and the end of the $21^{\text {st }}$ century are discussed. Since the often-used emission scenarios do not differ remarkably in the next few decades in terms of greenhouse gas emissions and global warming rates, in this paper only one of them is evaluated in case of the mid-century projections, whereas three different emission scenarios are analyzed for the later period of the century.

\section{Regional climate modelling using PRECIS}

The installation and the adaptation of the regional climate model PRECIS at the Department of Meteorology, Eötvös Loránd University started in 2004. The PRECIS is a high resolution limited area model with both atmospheric and land surface modules (Wilson, S. et al. 2010). The model was developed at the Hadley Climate Centre of the UK Met Office, and it can be used over any part of the globe (e.g. Hudson, D.A. and Jones, R.G. 2002; Rupa Kumar, K. et al. 2006; TAYLOR, M.A. et al. 2007; AKHTAR, M. et al. 2008). The PRECIS regional 
climate model is based on the atmospheric component of HadCM3 (Gordon, C. et al. 2000) with substantial modifications to the model physics (Jones, R.G. et al. 2004). The atmospheric component of PRECIS is a hydrostatic version of the full primitive equations and it applies a regular latitude-longitude grid in the horizontal and a hybrid vertical coordinate. The horizontal resolution can be set to $0.44^{\circ} \times 0.44^{\circ}$ or $0.22^{\circ} \times 0.22^{\circ}$, which gives a resolution of $\sim 50 \mathrm{~km}$ or $\sim 25$ $\mathrm{km}$, respectively, at the equator of the rotated grid (JonEs, R.G. et al., 2004). In our studies we used the finer horizontal resolution for modeling the Central European climate (Pongrácz, R. et al. 2010).

Hence the target region contains $123 \times 96$ grid points with special emphasis on the Carpathian Basin and its Mediterranean vicinity containing $105 \times 49$ grid points. There are 19 vertical levels in the model, the lowest at $\sim 50 \mathrm{~m}$ and the highest at $0.5 \mathrm{hPa}$ (Cullen, M.J.P. 1993) with terrain-following sigma coordinates (which is a ratio between the pressure at the coordinate level and the surface pressure) used for the bottom four levels, pressure coordinates for the top three levels and a combination in between (Simmons, A.J. and BuRridge, D.M. 1981). The model equations are solved in spherical polar coordinates and the latitude-longitude grid is rotated so that the equator lies inside the region of interest in order to obtain quasi-uniform grid box area throughout the region. An Arakawa B grid (Arakawa, A. and Lamb, V.R. 1977) is used for horizontal discretization to improve the accuracy of the split-explicit finite difference scheme. Due to its fine resolution, the model requires a time step of 5 minutes to maintain numerical stability (Jones, R.G. et al. 2004). In the post processing of the RCM outputs, daily mean values are used.

The necessary initial and lateral boundary conditions for PRECIS runs are provided by the HadCM3 ocean-atmosphere coupled GCM (Gordon, C. et al. 2000; RoweLL, D.P. 2005) using $150 \mathrm{~km}$ as a horizontal resolution. The reference period used in our studies is set to 1961-1990. For the future (2071-2100), three experiments were completed (BARTHOLY, J. et al. 2009a; PieczKa I. et al. 2009, 2011), namely, the A2, A1B, and B2 global emission scenarios (NAKicenovic, N. and SwART, R. 2000). The estimated global mean $\mathrm{CO}_{2}$ concentration level for the end of the century is $856 \mathrm{ppm}, 717 \mathrm{ppm}$, and $621 \mathrm{ppm}$, respectively. Thus, A2 can be considered the most pessimistic, and B2 the most optimistic among the scenarios. Our findings for the projected change of temperature and precipitation (compared to 1961-1990) are discussed in the next section.

\section{Results}

RCM simulations provide time series of more than 100 meteorological variables for each grid cell. In this paper we focus on the two most important variables describing climatic conditions, namely, temperature and precipitation. We discuss the projected changes of both the mean and the extreme values. 
In the past (1961-1990) the annual mean temperature values for Hungary were between $8{ }^{\circ} \mathrm{C}$ and $11^{\circ} \mathrm{C}$, however, most of the area could be characterized by $10-11^{\circ} \mathrm{C}$. Due to the annual temperature cycle, seasonal mean temperature values in spring and autumn did not differ significantly from the annual means. In winter the seasonal mean temperature was between $-2{ }^{\circ} \mathrm{C}$ and $+1^{\circ} \mathrm{C}$, the area of the country could be divided into two large regions: in the southwestern part the values were above the freezing point, whereas in the northeastern part they were below $0{ }^{\circ} \mathrm{C}$. In summer the seasonal mean temperature was between $17^{\circ} \mathrm{C}$ and $21^{\circ} \mathrm{C}$, however, the majority of the country area experienced a summer mean temperature above $19^{\circ} \mathrm{C}$.

The projected seasonal temperature increases averaged for the entire country are summarized in Table 1. The projected summer warming is the largest among the four seasons. Evidently the warming signal is the largest in the case of A2 scenario, while B2 and A1B scenarios indicate somewhat less future warming, which can be explained by the estimated lower $\mathrm{CO}_{2}$ concentration compared to A2. The projected annual mean temperature increase for Hungary is about $2.6^{\circ} \mathrm{C}$ by the middle of the century, and $4.0-5.4^{\circ} \mathrm{C}$ by the end of the century.

Table 1. Projected seasonal mean temperature change $\left({ }^{\circ} \mathrm{C}\right)$ in Hungary (Reference period 1961-1990)*

\begin{tabular}{c|c|c|c|c|c}
\hline \multicolumn{2}{c|}{$\begin{array}{c}\text { Changes of } \mathrm{T}_{\text {mean }}{ }^{\circ} \mathrm{C}, \\
\text { compared to } 1961-1990\end{array}$} & Winter & Spring & Summer & Autumn \\
\hline $2021-2050$ & A1B & 2.5 & 1.9 & 3.7 & 2.2 \\
\hline \multirow{2}{*}{$2071-2100$} & B2 & 3.2 & 3.1 & 6.0 & 3.9 \\
& A1B & 4.1 & 3.7 & 6.7 & 5.0 \\
& A2 & 4.2 & 4.2 & 8.0 & 5.2 \\
\hline
\end{tabular}

* All the projected warming rates are significant at 0.05 level.

Table 2 summarizes the projected seasonal mean precipitation changes. The largest changes are estimated for summer, for which the drying trends are significant at 0.05 level by the end of the $21^{\text {st }}$ century in the entire country in case of all the three scenarios.

The projected change in the annual distribution of the simulated monthly mean precipitation is shown in Figure 1.

In the present climate (1961-1990), the wettest months in Hungary are in late spring, early summer (May, June) when the monthly mean precipitation sum exceeds $60 \mathrm{~mm}$. The driest months are January and February with about $30 \mathrm{~mm}$ total precipitation on the average. The PRECIS simulations suggest that the annual distribution of monthly precipitation is very likely to be restructured in the future. The driest months will no longer occur during winter, but in July and August (with about $20-30 \mathrm{~mm}$ precipitation on aver- 
Table 2. Projected seasonal mean precipitation change in Hungary

(Reference period 1961-1990)*

\begin{tabular}{l|c|c|c|c|c}
\hline \multirow{2}{*}{$\begin{array}{c}\text { Precipitation changes } \\
\text { compared to 1961-1990 }\end{array}$} & Winter & Spring & Summer & Autumn \\
\cline { 2 - 6 } & A1B & 13 & 2 & -17 & 8 \\
\hline $2021-2050$ & B2 & -6 & -8 & -43 & -18 \\
$2071-2100$ & A1B & 34 & 5 & -33 & -4 \\
& A2 & 14 & -13 & -58 & -8 \\
\hline
\end{tabular}

* Characters in italics indicate significant projected changes at 0.05 level

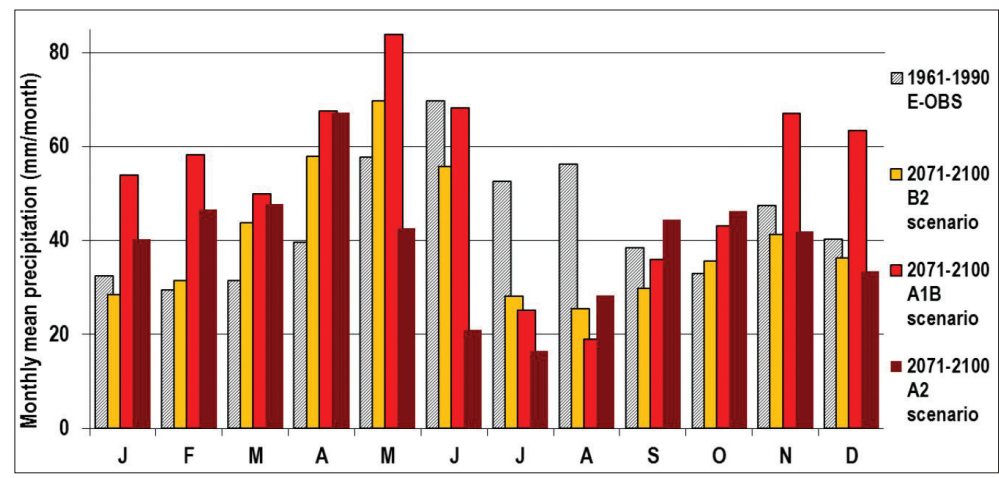

Fig. 1. Annual distribution of observed and simulated monthly mean precipitation in the reference period (1961-1990) and in the future (2071-2100)

age by 2071-2100) according to current projections. A2 simulation suggests an average value less than $20 \mathrm{~mm}$ which is significantly lower than the present value and the value of the two other scenarios. The wettest month of the A2 scenario run is projected to be April with about $65-70 \mathrm{~mm}$ precipitation on the average, while in the case of the $\mathrm{B} 2$ and $\mathrm{A} 1 \mathrm{~B}$ simulations the wettest months are April, May and June with about $60 \mathrm{~mm}$ (B2) or even more than $60 \mathrm{~mm}$ (A1B) total mean precipitation on average.

The projected precipitation tendencies and the inter-annual variability for the summer and winter seasons in the case of A1B scenario are illustrated in Figure 2. The negative trend in summer and the positive trend in winter are both evident. Moreover, the variability of winter precipitation is likely to increase in the $21^{\text {st }}$ century.

For end-users it is also important to have information on the projected climate change. Projected seasonal mean temperature and precipitation changes for Hungary are combined in Figure 3. By the end of the century the summers are likely to be warmer and drier, whereas the winters milder and wetter. In spring and autumn warming trends are projected, but the simulated changes in precipitation are small (less than $20 \%$ ) and not significant at 0.05 level. 


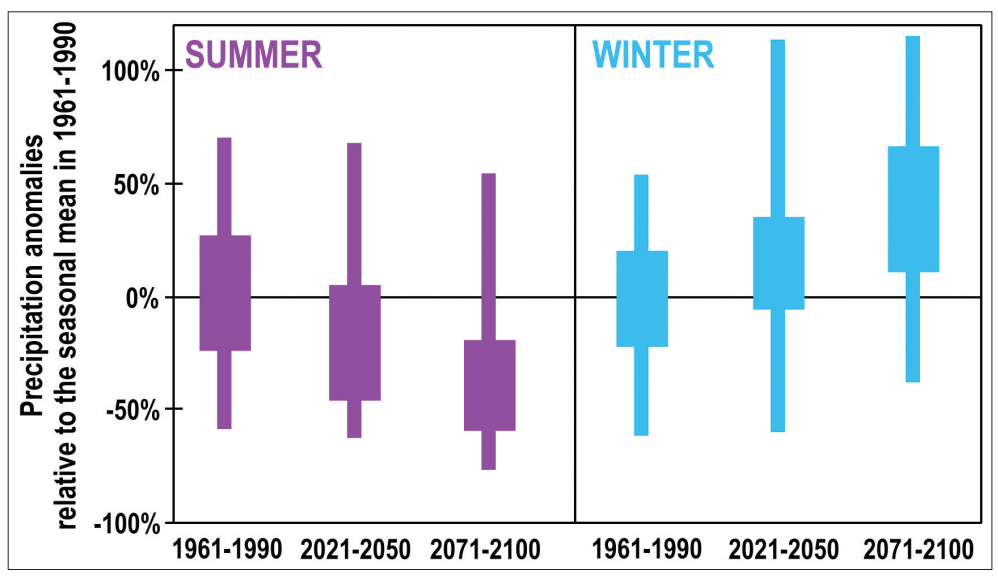

Fig. 2. Projected changes of summer and winter precipitation by the mid- and late century decades (A1B scenario), reference period: 1961-1990. Thin columns indicate the extremes of the period. Thick boxes show the middle $50 \%$ range (between the lower and the upper quartiles)
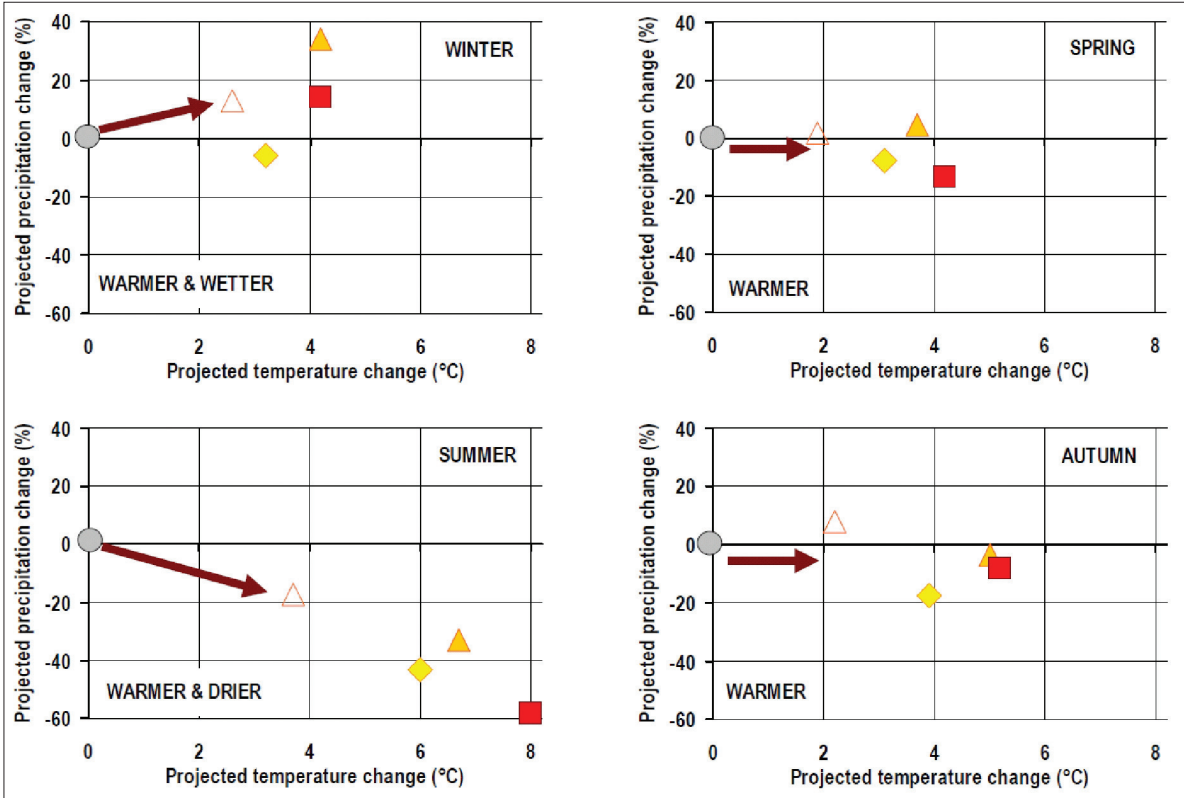

Fig. 3. Projected seasonal temperature and precipitation change in Hungary for the $21^{\text {st }}$ century based on PRECIS-simulations, reference period: 1961-1990 (indicated by the grey circle). Empty and filled symbols indicate the projected changes by 2021-2050 and by 2071-2100, respectively. Red squares, orange triangles and yellow romboids indicate the results for the different scenarios (A2, A1B, and $\mathrm{B} 2$, respectively) 
In order to develop appropriate adaptation strategies besides the mean changes, it is especially important to provide estimation of extremes. First, the daily minimum and maximum temperatures are analyzed here. In the reference period (1961-1990), the annual average of daily minimum temperature values in Hungary were $3-7^{\circ} \mathrm{C}$ (based on the gridded E-OBS data, HAYLOCK, M.R. et al. 2008) and in the central region of the country it exceeded $6^{\circ} \mathrm{C}$. The annual average of the daily maximum temperature values were $13-16^{\circ} \mathrm{C}$ and in the southeastern part of the country it exceeded $15^{\circ} \mathrm{C}$. In the warmest part of the year, in summer, the averages of the daily minimum and maximum temperatures were $12-15{ }^{\circ} \mathrm{C}$ and $24-27^{\circ} \mathrm{C}$, respectively.

In winter, the averages of the daily minimum temperature were mainly between $-4{ }^{\circ} \mathrm{C}$ and $-2{ }^{\circ} \mathrm{C}$ with the exception of the northeastern regions of the country with average daily minimum temperatures between $-6{ }^{\circ} \mathrm{C}$ és $-4{ }^{\circ} \mathrm{C}$. The winter averages of the daily maximum temperature were $1-4^{\circ} \mathrm{C}$. The extreme daily values above are projected to increase similarly to the daily mean temperature values. Table 3 summarizes the projected warming concerning the daily minimum and maximum temperatures (upper and lower part of Table 1, respectively). The largest projected changes and the largest uncertainty due to different scenarios are both in summer.

After analyzing the daily extreme values, several extreme temperature indices were calculated since they provide useful information on extreme climatic conditions. Table 4 summarizes the definitions and the observed average values (based on the gridded E-OBS data, HAYLOCK, M.R. et al. 2008) of the following temperature indices for Hungary: the number of frost days, summer days, hot days, extremely hot days and heat wave days. Table 4 also summarizes the projected changes averaged for the grid cells located in Hungary by the mid-and the late $21^{\text {st }}$ century compared to the reference period.

Table 3. Projected seasonal mean change in daily minimum and maximum temperature $\left({ }^{\circ} \mathrm{C}\right)$ in Hungary (Reference period 1961-1990)

\begin{tabular}{|c|c|c|c|c|c|}
\hline \multicolumn{2}{|c|}{$\begin{array}{c}\text { Changes of } \mathrm{T}_{\min }{ }^{\circ} \mathrm{C}, \\
\text { compared to } 1961-1990\end{array}$} & Winter & Spring & Summer & Autumn \\
\hline $2021-2050$ & A1B & 2.7 & 1.9 & 3.5 & 2.3 \\
\hline 2071-2100 & $\begin{array}{c}\text { B2 } \\
\text { A1B } \\
\text { A2 }\end{array}$ & $\begin{array}{l}3.3 \\
4.3 \\
4.2 \\
\end{array}$ & $\begin{array}{l}2.9 \\
3.9 \\
4.1 \\
\end{array}$ & $\begin{array}{l}5.3 \\
6.3 \\
7.1 \\
\end{array}$ & $\begin{array}{l}3.7 \\
5.1 \\
5.0\end{array}$ \\
\hline \multicolumn{2}{|c|}{$\begin{array}{c}\mathrm{T}_{\max }{ }^{\circ} \mathrm{C}, \\
\text { compared to } 1961-1990\end{array}$} & Winter & Spring & Summer & Autumn \\
\hline $2021-2050$ & A1B & 2.5 & 2.0 & 4.0 & 2.1 \\
\hline 2071-2100 & $\begin{array}{c}\text { B2 } \\
\text { A1B } \\
\text { A2 }\end{array}$ & $\begin{array}{l}3.4 \\
4.2 \\
4.0\end{array}$ & $\begin{array}{l}3.3 \\
3.9 \\
4.5\end{array}$ & $\begin{array}{l}6.6 \\
7.2 \\
8.7\end{array}$ & $\begin{array}{l}4.0 \\
5.3 \\
5.2\end{array}$ \\
\hline
\end{tabular}


Table 4. Observed average values and projected changes in the $21^{\text {st }}$ century for extreme temperature indices for Hungary

\begin{tabular}{l|c|c|c|c|c}
\hline \multicolumn{1}{c|}{ Indices } & $\begin{array}{c}\text { Average, } \\
\text { days }\end{array}$ & \multicolumn{4}{|c}{ Projected change, days } \\
\hline $\begin{array}{c}\text { Temperature index } \\
\text { (Definition) }\end{array}$ & $\begin{array}{c}1961-1990 \\
\text { E-OBS }\end{array}$ & $\begin{array}{c}2021-2050 \\
\text { A1B }\end{array}$ & $\begin{array}{c}2071-2100 \\
\text { B2 }\end{array}$ & $\begin{array}{c}2071-2100 \\
\text { A1B }\end{array}$ & $\begin{array}{c}2071-2100 \\
\text { A2 }\end{array}$ \\
\hline $\begin{array}{l}\text { Number of frost days } \\
\left(\mathrm{T}_{\min }<0^{\circ} \mathrm{C}\right)\end{array}$ & 93.0 & -35 & -43 & -54 & -51 \\
\hline $\begin{array}{l}\text { Number of summer } \\
\text { days }\left(\mathrm{T}_{\max }>25^{\circ} \mathrm{C}\right)\end{array}$ & 67.0 & 38 & 66 & 68 & 76 \\
\hline $\begin{array}{l}\text { Number of hot days } \\
\left(\mathrm{T}_{\max }>30^{\circ} \mathrm{C}\right)\end{array}$ & 14.0 & 34 & 68 & 65 & 86 \\
\hline $\begin{array}{l}\text { Number of extremely } \\
\text { hot days }\left(\mathrm{T}_{\max }>35^{\circ} \mathrm{C}\right)\end{array}$ & 0.3 & 12 & 30 & 34 & 53 \\
\hline $\begin{array}{l}\text { Number of heat wave } \\
\text { days }\left(\mathrm{T}_{\operatorname{mean}}>25^{\circ} \mathrm{C}\right)\end{array}$ & 4.0 & 30 & 59 & 59 & 80 \\
\hline
\end{tabular}

Statistically significant decrease of the annual number of frost days is projected which is a clear consequence of the overall warming tendency. For the same reason the average annual numbers of summer days, hot days, extremely hot days and heat wave days are projected to increase significantly in the country. The projected changes by 2021-2050 are about the half of those by 2071-2100. The largest changes are projected in the A2 scenario, which estimates the highest $\mathrm{CO}_{2}$ level by the end of the $21^{\text {st }}$ century.

The detailed spatial structures of the projected changes of extreme temperature indices are shown in Figures 4-8. The regional temperature-related climatic changes projected for the different emissions scenarios are not

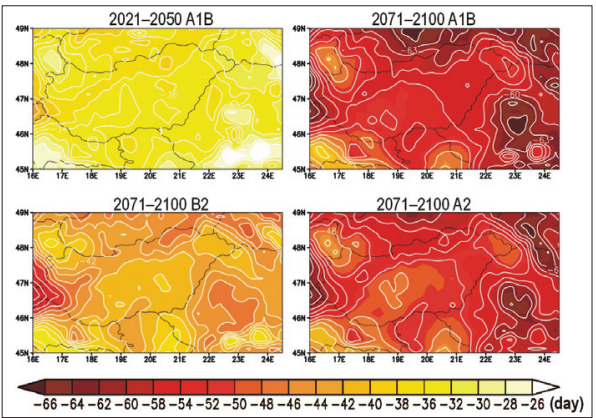

Fig. 4. Projected changes in the number of frost days $\left(\mathrm{T}_{\min }<0{ }^{\circ} \mathrm{C}\right)$ compared to the reference period (1961-1990) substantially different by the middle of the century. The scenario-related contributions to the total uncertainty for Europe does not exceed 25\% for a few decades ahead, whereas it is about $70 \%$ for a century ahead (Hawkins, E. and Sutton, R. 2009). Therefore the projected changes are mapped for the three different scenarios by the end of the $21^{\text {st }}$ century and for only A1B scenario by the middle of the century.

Larger decreases of the number of frost days are indicated by darker colors (Figure 4). The overall 
structures of the simulated changes are quite similar: the annual number of frost days is projected to decrease more in the higher elevated regions than in the lowland areas.

On the maps indicating the projected changes of warm extremes, the larger increases are shown by darker colors (Figures 5-8). The annual number of summer, hot and extremely hot days are all defined using daily maximum temperatures with increasing limit values $\left(25^{\circ} \mathrm{C}, 30^{\circ} \mathrm{C}\right.$, and $35^{\circ} \mathrm{C}$, respectively). However, the spatial structures of the projected changes of summer days (Figure 5) are more similar to those of the frost days than those of the hot (Figure 6) or extremely hot (Figure 7) days.

Besides the topography effect, zonal structures can also be recognized on the maps indicating the projected changes of the hot and extremely hot days. The projected increases are larger in the southern part of Hungary than in the northern regions. Similar structures dominate the maps indicating the projected changes of the heat wave days (Figure 8).

Finally, the precipitation related climate indices (e.g. the number of wet days exceeding different threshold values, the maximum length of dry periods, intensity) are analyzed. Table 5 summarizes the definitions and the observed annual average values (based on the gridded E-OBS data, HAYLOCK, M.R. et al. 2008) for Hungary.

Table 5 contains the projected annual changes averaged for the grid cells located within the country by the mid- and the late century compared to

Table 5. Observed average annual values and projected annual changes in the $21^{\text {st }}$ century in case of precipitation indices for Hungary

\begin{tabular}{|c|c|c|c|c|c|}
\hline Indices & $\begin{array}{l}\text { Average, } \\
\text { days }\end{array}$ & \multicolumn{4}{|c|}{ Projected change, days } \\
\hline Precipitation index (Definition) & $\begin{array}{c}1961- \\
1990 \\
\text { E-OBS }\end{array}$ & $\begin{array}{c}2021- \\
2050 \\
\text { A1B }\end{array}$ & $\begin{array}{c}2071- \\
2100 \\
\text { B2 }\end{array}$ & $\begin{array}{c}2071- \\
2100 \\
\text { A1B }\end{array}$ & $\begin{array}{c}2071- \\
2100 \\
\text { A2 }\end{array}$ \\
\hline $\begin{array}{l}\text { Number of precipitation days ex- } \\
\text { ceeding } 1 \mathrm{~mm}, \mathrm{RR} 1\left(\mathrm{R}_{\mathrm{day}}>1 \mathrm{~mm}\right)\end{array}$ & 106.0 & -8.0 & -21.0 & -15.0 & -24.0 \\
\hline $\begin{array}{l}\text { Number of precipitation days ex- } \\
\text { ceeding } 5 \mathrm{~mm}, \mathrm{RR} 5\left(\mathrm{R}_{\mathrm{dav}}>5 \mathrm{~mm}\right)\end{array}$ & 36.0 & -1.0 & -8.0 & -2.0 & -10.0 \\
\hline $\begin{array}{l}\text { Number of precipitation days ex- } \\
\text { ceeding } 10 \mathrm{~mm}, \mathrm{RR} 10\left(\mathrm{R}_{\mathrm{dav}}>10 \mathrm{~mm}\right)\end{array}$ & 11.0 & 2.0 & -3.0 & 2.0 & -3.0 \\
\hline $\begin{array}{l}\text { Number of precipitation days ex- } \\
\text { ceeding } 20 \mathrm{~mm}, \mathrm{RR} 20\left(\mathrm{R}_{\mathrm{day}}>20 \mathrm{~mm}\right)\end{array}$ & 1.3 & 0.9 & -0.7 & 1.3 & -0.2 \\
\hline $\begin{array}{l}\text { Maximum number of consecutive } \\
\text { dry days, } C D D\left(R_{\mathrm{dav}}<1 \mathrm{~mm}\right)\end{array}$ & 28.0 & 3.0 & 5.0 & 10.5 & 9.0 \\
\hline $\begin{array}{l}\text { Simple daily precipitation intensity, } \\
\text { SDII }\left(\mathrm{R}_{\mathrm{vea}} / \mathrm{RR} 1\right)\end{array}$ & $4.8^{*}$ & $0.4^{*}$ & $-0.1^{*}$ & $0.7^{*}$ & $-0.0^{*}$ \\
\hline
\end{tabular}




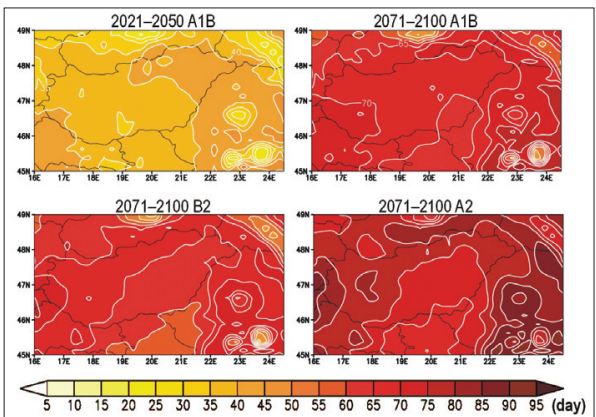

Fig. 5. Projected changes in the number of summer days $\left(\mathrm{T}_{\max }>25^{\circ} \mathrm{C}\right)$ compared to the reference period (1961-1990)

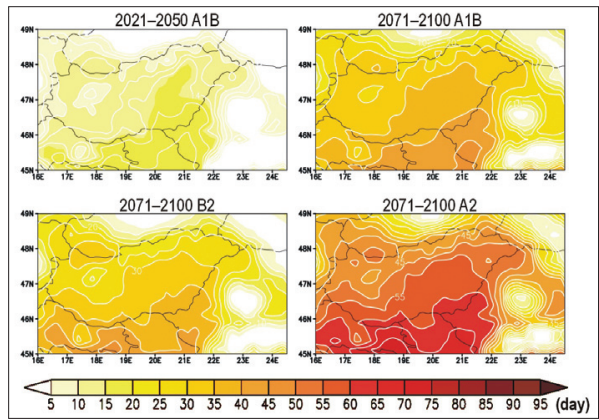

Fig. 7. Projected changes in the number of extremely hot days $\left(\mathrm{T}_{\max }>35^{\circ} \mathrm{C}\right)$ compared to the reference period (1961-1990)

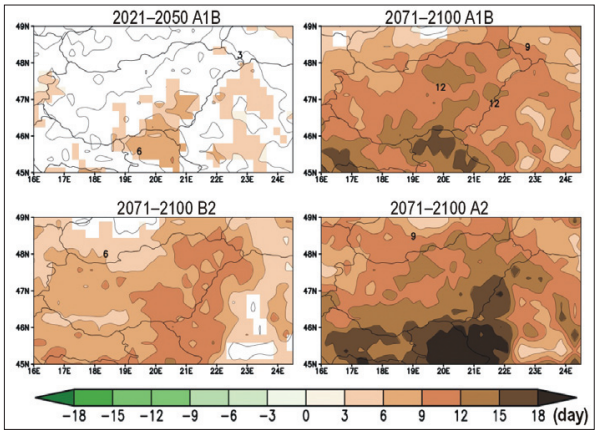

Fig. 9. Projected seasonal changes in CDD, the maximum number of consecutive dry days $\left(\mathrm{R}_{\text {day }}<1 \mathrm{~mm}\right)$ in summer compared to the reference period (1961-1990). Only the statistically significant changes are colored in the maps

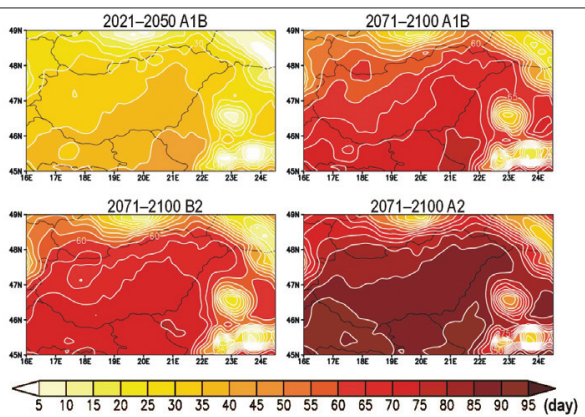

Fig. 6. Projected changes in the number of hot days $\left(\mathrm{T}_{\max }>30^{\circ} \mathrm{C}\right)$ compared to the reference period (1961-1990)

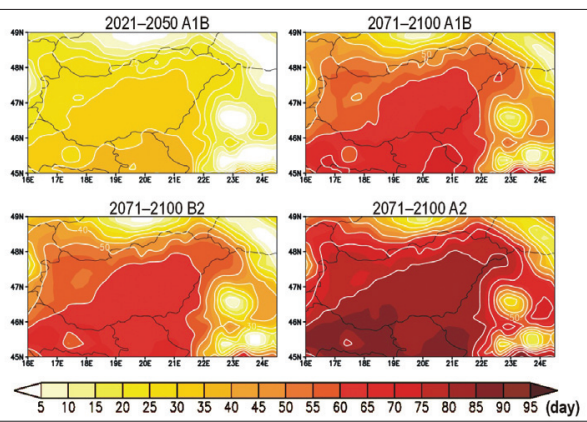

Fig. 8. Projected changes in the number of heat wave days $\left(\mathrm{T}_{\text {mean }}>25^{\circ} \mathrm{C}\right)$ compared to the reference period (1961-1990)

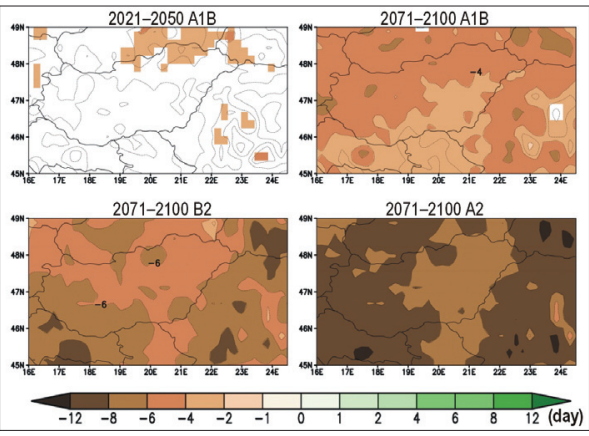

Fig. 10. Projected seasonal changes in RR5, the number of precipitation days $\left(R_{\text {day }}>5\right.$ $\mathrm{mm}$ ) in summer compared to the reference period (1961-1990). Only the statistically significant changes are colored in the maps 
the reference period. Projected changes of large precipitation days (exceeding $5 \mathrm{~mm}, 10 \mathrm{~mm}, 20 \mathrm{~mm}$, etc.) in the $21^{\text {st }}$ century are highly uncertain, whereas the annual number of precipitation days exceeding only $1 \mathrm{~mm}$ (RR1) is projected to decrease. The length of dry periods, i.e. the maximum number of consecutive dry days (CDD) is likely to increase in the future. The estimated changes for Hungary by the end of the century are statistically significant in summer (Figure 9), suggesting longer and more persistent dry spells.

Due to the overall projected summer precipitation decrease, the PRECIS-simulations point to a considerable increase of the drought risks in the country, especially in the regions near the southern and eastern borders. Figure 10 indicates the projected changes of precipitation days exceeding $5 \mathrm{~mm}$ (RR5) in summer. The estimated changes are not significant in the other three seasons, neither in the summer by the mid-century.

However, by the end of the century the numbers of summer precipitation days exceeding $5 \mathrm{~mm}$ are projected to decrease in Hungary. The estimated decreases are larger in Transdanubia than in the eastern regions of the country. The largest decrease is estimated by the most pessimistic (A2) scenario.

\section{Conclusions}

Future climatic conditions of Hungary in the $21^{\text {st }}$ century were estimated and analyzed using the PRECIS regional climate model simulations considering three different emissions scenarios (A2, A1B, B2). The following conclusions can be drawn.

- Temperature is projected to increase in the next decades. The projected increase of annual mean temperature by the late-century compared to the $1961-1990$ reference period is $4.0-5.4{ }^{\circ} \mathrm{C}$. The projected seasonal warming is the largest in summer.

- The projected regional warming in Hungary is the largest in case of the A2 scenario, according to which the highest $\mathrm{CO}_{2}$ concentration level is estimated.

- As a consequence of the regional warming trend, more frequent warm and hot events and greater record hot conditions are projected for the future compared to the 1961-1990 reference period.

- The annual distribution of monthly mean precipitation is projected to change. The wettest months in Hungary are likely to shift from May and June to April and May, whereas the driest months from January and February to July and August.

- Significant drying is projected for Hungary, especially, in summer. The seasonal precipitation amounts are likely to decrease and the probability of drought occurrence is estimated to increase.

These results provide important information for both decision makers and civil associations. In addition, they play a key role in developing appropriate adaptation strategies in the coming decades. 
Acknowledgements: Research leading to this paper was supported by the following sources: the Hungarian Scientific Research Fund under grants K-78125 and K-83909 the Swiss Hungarian Cooperation Programme (SH/2/1), the European Union and the European Social Fund through project FuturICT.hu (TÁMOP-4.2.2.C-11/1/KONV-2012-0013), also other projects (TÁMOP-4.2.1/B-09/1/KMR-2010-0003, TÁMOP-4.1.2.A/1-11/1-2011-0073, GOP-1.1.1.-11-2012-0164, KMR_12-1-2012-0206). We also acknowledge the E-OBS dataset from the EU-FP6 project ENSEMBLES (http://ensembles-eu.metoffice.com) and the data providers in the ECA\&D project (http://eca.knmi.nl).

\section{REFERENCES}

Aкhtar, M., Ahmad, N. and Booij, M.J. 2008. The impact of climate change on the water resources of Hindukush-Karakorum-Himalaya region under different glacier coverage scenarios. Journal of Hydrology 355. (1-4): 148-163.

Arakawa, A. and Lamb, V.R. 1977. Computational design of the basic dynamical processes of the UCLA general circulation model. In Methods in Computational Physics 17. Ed. Chang, J. New York, Academic Press, 173-265.

Bartholy, J., Pongrácz, R., Pieczka, I., Kardos, P. and Hunyady, A. 2009a. Analysis of expected climate change in the Carpathian Basin using a dynamical climate model. Lecture Notes in Computer Science 5434. 176-183.

Bartholy, J., Pongrácz, R., Torma, Cs., Pieczka, I., Kardos, P. and Hunyady, A. 2009b. Analysis of regional climate change modelling experiments for the Carpathian basin. International Journal of Global Warming 1. 238-252.

Cullen, M.J.P. 1993. The unifed forecast/climate model. Meteorological Magazine 122. 81-94.

Giorgi, F. 1990. Simulation of regional climate using a limited area model nested in a general circulation model. Journal of Climate 3. 941-963.

Gordon, C., Cooper, C., Senior, C.A., Banks, H., Gregory, J.M., Johns, T.C., Mitchell, J.F.B. and Woop, R.A. 2000. The simulation of SST, sea ice extents and ocean heat transports in a version of the Hadley Centre coupled model without flux adjustments. Climate Dynamics 16. 147-168.

Hawkins, E. and Sutton, R. 2009. The Potential to Narrow Uncertainty in Regional Climate Predictions. Bulletin of American Meteorological Society 90. 1095-1107. doi: http://dx.doi. org/10.1175/2009BAMS2607.1

Haylock, M.R., Hofstra, N., Klein Tank, A.M.G., Klok, E.J., Jones, P.D. and New, M. 2008. A European daily high-resolution gridded dataset of surface temperature and precipitation. Journal of Geophysics Res (Atmospheres) 113. D20119, doi:10.1029/2008 JD010201.

Hudson, D.A. and Jones, R.G. 2002. Regional climate model simulations of present-day and future climates of Southern Africa. Technical Notes No. 39. UK Meteorological Office Hadley Centre, Bracknell. 42 p.

IPCC, 2013. Climate Change 2013: The Physical Science Basis. Contribution of Working Group I to the Fifth Assessment Report of the Intergovernmental Panel on Climate Change. Eds. Stocker, T.F., Qin, D., Plattner, G.-K., Tignor, M., Allen, S.K., Boschung, J., Nauels, A., XIA, Y., BeX, V. and Midgley, P.M., Cambridge-New York, Cambridge University Press, UK and USA.

Jones, R.G., Noguer, M., Hassell, D.C., Hudson, D., Wilson, S.S., Jenkins, G.J. and Mitchell, J.F.B. 2004. Generating high resolution climate change scenarios using PRECIS. Exeter, UK Meteorological Office, Hadley Centre, $40 \mathrm{p}$. 
LAKATOS, M. and Bihari, Z. 1013. A XX. század során észlelt hazai éghajlati változások. (Climate change perceptions in Hungary during the $20^{\text {th }}$ century) In Klímaváltozás. Eds. BArtholy, J. and Pongrácz, R. Budapest, ELTE TTK FFI Meteorológiai Tanszék, 27-49.

Nakicenovic, N. and Swart, R. eds. 2000. Emissions Scenarios. A special report of IPCC Working Group III. Cambridge-New York, Cambridge University Press, UK and USA, $570 \mathrm{p}$.

Pieczka, I., Bartholy, J., Pongrácz, R. and Hunyady, A. 2009. Climate change scenarios for Hungary based on numerical simulations with a dynamical climate model. Lecture Notes in Computer Science 5910. 613-620.

Pieczka, I., Pongrácz, R. and Bartholy, J. 2011. Comparison of simulated trends of regional climate change in the Carpathian Basin for the $21^{\text {st }}$ century using three different emission scenarios. Acta Silvatica et Lignaria Hungarica 7. 9-22.

Pongrácz, R., Bartholy, J., Pieczka I. and Torma Cs. 2010. Az ELTE regionális klímamodelljei: PRECIS és RegCM. (Regional climate models of the ELTE: PRECIS and RegCM). In 36. Meteorológiai Tudományos Napok: Változó éghajlat és következményei a Kárpátmedencében. Ed. Lakatos, M. Budapest, Országos Meteorológiai Szolgálat, 102-112. http://www.met.hu/downloads.php?fn=/metadmin/attach/2013/02/36-meteorologiaitudomanyos-napok-osszefoglalo-2010.pdf

Rowell, D.P. 2005. A scenario of European climate change for the late $21^{\text {st }}$ century: seasonal means and interannual variability. Climate Dynamics 25. 837-849.

Rupa Kumar, K., Sahai, A.K., Krishna Kumar, K., Patwardhan, S.K., Mishra, P.K., Revadekar, J.V., Kamala, K. and Pant, G.B. 2006. High-resolution climate change scenarios for India for the $21^{\text {st }}$ century. Current Science 90. 334-345.

Simmons, A.J. and BurRidge, D.M. 1981. An energy and angular-momentum conserving vertical finite difference scheme and hybrid vertical coordinates. Monthly Weather Review 109. 758-766.

Taylor, M.A., Centella, A., Charlery, J., Borrajero, I., Bezanilla, A., Campbell, J., Rivero, R., Stephenson, T.S., Whyte, F. and Watson, R. 2007. Glimpses of the Future: A Briefing from the PRECIS Caribbean Climate Change Project. Belmopan, Caribbean Community Climate Change Centre, Belize, $24 \mathrm{p}$.

Wilson, S., Hassell, D., Hein, D., Morrell, C., Jones, R. and TAYlor, R. 2010. Installing and using the Hadley Centre regional climate modelling system, PRECIS. Version 1.9.2. Exeter, UK Meteorological Office, Hadley Centre, $157 \mathrm{p}$.

WMO, 2013. The State of Greenhouse Gases in the Atmosphere Based on Global Observations through 2012. Greenhouse Gas Bulletin No. 9, 6 November 2013. http://www.wmo. int/pages/prog/arep/gaw/ghg/GHGbulletin.html 


\title{
Hungary in Maps
}

\author{
Edited by \\ Károly Kocsis and Ferenc Schweitzer
}

\section{Geographical Research Institute Hungarian Academy of Sciences Budapest, 2009. 212 p.}

\begin{abstract}
'Hungary in Maps' is the latest volume in a series of atlases published by the Geographical Research Institute of the Hungarian Academy of Sciences. A unique publication, it combines the best features of the books and atlases that have been published in Hungary during the last decades. This work provides a clear, masterly and comprehensive overview of present-day Hungary by a distinguished team of contributors, presenting the results of research in the fields of geography, demography, economics, history, geophysics, geology, hydrology, meteorology, pedology and other earth sciences. The 172 lavish, full-colour maps and diagrams, along with 52 tables are complemented by clear, authoritative explanatory notes, revealing a fresh perspective on the anatomy of modern day Hungary. Although the emphasis is largely placed on contemporary Hungary, important sections are devoted to the historical development of the natural and human environment as well.
\end{abstract}

In its concentration and focus, this atlas was intended to act as Hungary's 'business card', as the country's résumé, to serve as an information resource for the sophisticated general reader and to inform the international scientific community about the foremost challenges facing Hungary today, both in a European context and on a global scale. Examples of such intriguing topics are: stability and change in the ethnic and state territory, natural hazards, earthquakes, urgent flood control and water management tasks, land degradation, the state of nature conservation, international environmental conflicts, the general population decline, ageing, the increase in unemployment, the Roma population at home and the situation of Hungarian minorities abroad, new trends in urban development, controversial economic and social consequences as a result of the transition to a market economy, pri-

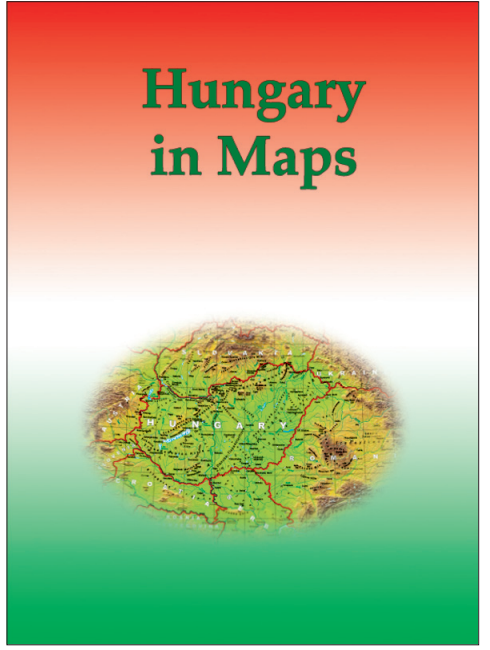
vatisation, the massive influx of foreign direct investment, perspectives on the exploitation of mineral resources, problems in the energy supply and electricity generation, increasing spatial concentration focused on Budapest in the field of services (e.g. in banking, retail, transport and telecommunications networks), and finally the shaping of an internationally competitive tourism industry, thus making Hungary more attractive to visit.

This project serves as a preliminary study for the new, 3rd edition of the National Atlas of Hungary, that is to be co-ordinated by the Geographical Research Institute of the Hungarian Academy of Sciences.

Price: EUR 20.00

Order: Geographical Institute RCAES HAS Library

H-1112 Budapest, Budaörsi út 45.

E-mail: magyar.arpad@csfk.mta.hu 